\title{
Geology, Geochemistry and Geochronology of the Gold mineralization hosting Syenite, Tulu Kapi, Western Ethiopia: A Review
}

\author{
${\text { Temesgen } \text { Oljira }^{1 * 2} \text { and Geleta Warkisa }}^{1}$ \\ ${ }^{1}$ Department of Geology, Faculty of Natural Sciences, Salale University, P. O. Box 245, \\ Fiche, Ethiopia \\ ${ }^{2}$ Pan African University Institute of Life and Earth Science Including Health and Agriculture \\ (PAULESI), Ibadan, Nigeria
}

\begin{abstract}
The Neoproterozoic (900-600 Ma) Arabian Nubian Shield is an example of Precambrian plate tectonics and arc accretion. The Western Ethiopian Shield (the southern extension of ANS) is geo-tectonically a characteristic of lower grades of Metavolcanosedimentary sequences of ANS intruded by associated felsic granitoid and mafic bodies and at the same time it is contained of gneisses rocks of the MB. The Gold mineralization and alterations initiating throughout the Tulu Kapi syenite are in the form of in enechelon vein arrays and related structures, which are controlled by conjugate shear zones in the syenite and steep N-S striking structures. The earliest recorded deformation and alterations revealed the syenite albitization which is the one hosting for gold mineralization and it has been widely overprinted by multistage hydrothermal system that appears to have been controlled mainly by veins, crackle zones, fractures and minor breccia zones. Primary gold mineralization displays spatial and temporal relationship with Tulu Kapi syenite and the Kapi gabbro, both of which host gold mineralization, are 738.3 $\pm 2.6 \mathrm{Ma}$ and $699.5 \pm 2.7 \mathrm{Ma}$ period, respectively, in a volcanic arc subduction syn-collisional tectonic setting by the fractionation of underplated, LREE-enriched basaltic magma with substantial crustal input to possible crustal melting. The underplated basaltic magma had been sourced from LREE-enriched mantle by subduction of sediment laden crustal slabs at a subduction zone. Fractional crystallization involved formation of Ca-rich plagioclase, which continually reacted with hydrothermal fluids to more fractionated
\end{abstract}


Na-rich plagioclase, forming the gold mineralization hosting altered (albitized) syenites. The Pan-African orogeny, and associated regional metamorphism and magmatism, generated largescale movements of gold and base metal-bearing fluids in the crust, channelized along complex fractures into regional NE-SW foliation in Ethiopia (e.g., western Ethiopia). However, these gold-rich alkalic magmas are so modified by crustal processes that evidence of their genetic relationship with gold become obscured. The primary ore mineral assemblage of quartz veins and veinlets, and associated mineralized syenite within Tulu Kapi area consists of pyrite, galena, chalcopyrite, hematite, and gold. The major and trace element composition of oreforming fluids from the mineralized vein, barren and granitic intrusion is still largely unknown, yet could provide important and more direct evidence for the fluid source(s). This is vital in establishing a direct genetic link between syenite and other granitoid intrusion, and gold mineralization.

Keyword: Geology, Geochemistry, Geochronology, Gold mineralization, Syenite, Tulu Kapi

\section{Introduction}

The geology of Ethiopia has favored the emplacement of several mineral deposits such as gold (Au), Tantalum and Platinum, Phosphate, rutile, iron ore, bauxite and etc. (Tadesse, 2003). Au mineralization is usually spatially and temporally related to granitoids (Hart et.al., 2004, Goldfarb et.al., 2005). In Ethiopia a number of placer gold occurrences, as well as the Lega Dembi primary gold mining area, are known to date from the Precambrian basement rocks during or postdating granitic intrusion. These gold mineralization's occur in intensely sheared, hydrothermally altered greenschist facies volcano-sedimentary rocks of Megado and Kenticha belts in the southern part of the country (Deksisa and Koerbel, 2004), Meli, Weri and Werkamba area in the northern part of the country (Bheemalingeswara et.al., 2015) and granitoid of Western Ethiopian Shield (Mogossie et al., 2002). The low-grade volcano- 
sedimentary suites of WES are characteristic of the Arabian-Nubian Shield (ANS) of NE Africa, whilst the gneissic rocks are more akin to the gneisses of the Mozambique Belt (MB) of East Africa (Tadesse and Allen, 2004). Structural constraints (e.g. Johnson et al., 2004) suggested the steep $\mathrm{N}-\mathrm{S}$ striking structures dominating the basement fabrics in the EAO that were largely the result of $\mathrm{E}-\mathrm{W}$ crustal shortening related to terminal collision between East and West Gondwana.

Gold production in the Arabian Nubian Shield (ANS) dates to pre-historic times, with an estimated one-hundred million ounces mined (Molnar, 2019 and references there in). Today, gold is mined from the ANS in Egypt, Sudan, the Kingdom of Saudi Arabia, Eritrea and Ethiopia (Johnson et al., 2017). Earlier explorations and studies of gold mineralization in the ANS have mainly focused on the northern portion of the shield. The southern portion of the ANS, made up of the Western Ethiopian Shield (WES) and the Southern Ethiopian Shield (SES), has received much less attention. The shear zone hosted Lega Dembi Mine in the Adola Belt of the Southern Ethiopian Shield (Worku, 1996; Tadesse, 2003) is the only large-scale gold operation in the southern ANS (Molnar, 2019). Greenschist-facies orogenic belts and trans-continental shear zones that cut across the ANS in Ethiopia appear to be analogous to settings for structurally-controlled orogenic gold deposits around the world (Molnar, 2019). The WES is geologically comprised of Pan African low-grade volcano sedimentary sequences with felsic to mafic-ultramafic intrusions. (Kebede et al., 1999) broadly viewed the basement crystalline rocks in the western Ethiopian shield which in turn comprises two major rock groups: high-grade gneisses, which are often intensely migmatised, and volcano sedimentary greenschist assemblages with associated linear belts of ultramafic rocks at Yubdo Dalati-Tulu Dimtu (from south to north). Plutonic rocks of variable composition and age intruded the basement rocks, particularly the low-grade volcano-sedimentary sequence. Pre-, syn- and post tectonic plutonic suites constitute the basement and are dominated by granites and 
granodiorites. Therefore, there is good geological potential for additional gold deposits in the southern ANS.

Unlike the Southern Ethiopian Shield, the WES has no record of primary gold mining, except for unorganized placer and alluvial gold mining. This is probably due to the difficulty of access as well as extensive saprolite and regolith cover that complicates gold exploration (Molnar, 2019). One of the few documented gold deposits in the WES is Tulu Kapi. Thus, this work reviews the geology, geochemistry and geochronology and discusses the spatial and temporal relationship of the Syenite and the Gold mineralization of the Tulu Kapi Gold hosting Syenite, Western Ethiopia using published and unpublished works to give a comprehensive understanding about the formation of the Gold deposit within the frame work of the regional geological and tectonic setting.

\section{Geological and Tectonic Setting}

The ANS is an assemblage of the Neoproterozoic juvenile arcs, younger volcano sedimentary sequences intruded by voluminous felsic granitoid and mafic bodies that basically crop out in the western Arabian plate and the north-eastern African Plate at the northern end of the Eastern African orogeny (Johnson et al. 2011). It is commonly exposed in the Northern, southern and western Ethiopian shield with predominantly containing the exposures hosting for gold mineralization (Stern 1994, Molnar, 2019). The suture zones containing dismembered ophiolitic rocks of the WES has been interprets the linear belts of highly deformed maficultramafic bodies within low-grade (ANS-like) terrains of WES (e.g., Kazmin et al., 1978; Stern, 1994 and Johnson et al. 2004).

The western Precambrian terrain of Ethiopia is considered to comprehend lithological components similar to ANS to the North and MB to the southern (Kebede et al., 1999, Kazmin 
et al., 1978, 1979 and references therein). Corresponding to the other parts of the Arabian Nubian Shield, the western Precambrian basement in the perspective of the Western Ethiopia are grouped into older high-grade pre-Neoproterozoic gneisses, with slivers of supracrustal rocks, and Neoproterozoic (900-500 Ma), low-grade volcano-sedimentary sequences and associated dismembered mafic-ultramafic bodies. The units are intruded by syn-to posttectonic felsic to mafic plutons as suggested by (Johnson et al. 2011). On the other hand, the Western Ethiopian Shield is made up of a mosaic of high-grade rocks separated by lower-grade rocks. The Geotraverse in this WES perspective (Fig. 1) comprises three discrete lithotectonic units; from west to east, these are the Baro, Birbir, and Geba Domains (Ayalew, 1990). The Birbir domain has an ANS affinity and comprises low-grade metavolcano-sedimentary rocks containing bodies of highly altered ultramafic rocks, herein termed the Tulu Dimtu-DaletiYubdo belt (Johnson et al. 2011). The Birbir domain is tectonically bounded to the east and west, respectively, by the gneissic Geba and Baro domains (Fig. 1).

The Tulu Kapi area is underwent within the Birbir domain and lithologically it includes the lower-grade pelite, wacke, volcanic rocks, mylonite, and voluminous plutonic rocks. The Baro and Geba Domains from the western Ethiopian shield consist high grade rocks of heterogeneous ortho- and paragneisses and migmatites (Tefera and Berhe, 1987; Ayalew, 1988; Ayalew, 1990).

\section{The Tulu Kapi Gold Field}

The Tulu Kapi goldfield is confined within the Proterozoic Precambrian shield comprising of weakly metamorphosed low-grade volcano sedimentary sequences and high-grade gneissic rocks, which possibly represent the northern extension of the Mozambique Belt with associated mafic-ultramafic intrusions and syn-to post-tectonic gabbroic to granitic intrusions (Blades et al., 2015, Kebede et al., 1999). The area has been extensively folded, faulted and intruded by 
granites and lesser mafic to ultramafic intrusive and hosts a number of gold occurrences/deposits (Warkisa et al., 2020). The major rock units in the project area include metasandstones and undifferentiated metasediments, metatuff, meta-intrusive rocks (metagabbro, metadiorite and metagranite), and associated felsic (mafic syenite, porphyritic alkali syenite, quartz syenite) to mafic-ultramafic (chlorite-serpintinite-talc schist and undifferentiated ultramafics, birbirite) intrusions (Fig. 2). Mineralized smoky quartz veins and altered syenitic intrusions are the prominent host rocks of gold mineralization (Fig. 2). The dominant rock units are described below.

\subsection{Syenite}

The Tulu Kapi syenite lies on the west side of the Tulu Dimtu shear zone and in the hangingwall of its splay-fault, the Bedele shear zone (Molnar, 2019). It is bounded by fault structures, suggesting the involvement of, or control by, pre- to syn-genetic faults in the magmatic emplacement of the body (Kebede et al., 1999). The syenite hosting for the mineralization is occurs in the form of intrusion in the low-grade volcano sedimentary sequences. Compositionally, it ranges from quartz syenite to mafic syenite which ranges wide ranges of strain characteristics and comprised of albitization and sulphide mineralization. Some sheared altered and albitized domains of Syenite shows partial segregation of the magnetite-biotitic material from the quartzo-feldspathic minerals occurs, giving the rock a banded texture (Warkisa et al., 2020).

\subsection{Metadiorite}

The most intensely deformed and sheared part of the area and characterized by deformation fabric, alteration signatures and medium to coarse grained and equigranular but often showing porphyritic and pegmatitic in textures (Warkisa et al., 2020). 


\subsection{Gabbro}

Molnar, 2019 suggested that the Kapi gabbro which occurs immediately to the east of the Tulu Kapi syenite consisting of plagioclase, clinopyroxene hornblende and biotite. Plagioclase ranges from sub-cm to $5 \mathrm{~cm}$ in size, and texture varies from euhedral for the largest crystals to sub-cm sized anhedral plagioclase grains with irregular boundaries. Chlorite is found throughout the gabbro. The contact between the gabbro and syenite appears to be intrusive, but with some shearing or detachment with proximity to the Bedele shear zone.

\subsection{Metavolcano-sedimentary rocks}

A Metavolcano-sedimentary unit in the area is derived from the early alteration and combination of volcanic and sedimentary events and the ores occupying in the area is unlikely associated with variety of sedimentary, volcanic, and metamorphic environments (Warkisa et al., 2020). In the Tulu Kapi area these rock units are cut by various intrusions and much of it transformed to sericite and mafic schists. The volcanic rocks in the area are tectonically cross cut by syenitic dykes and a similar suite of dykes as the Tulu Kapi syenite (Molnar, 2019).

\subsection{Mafic-ultramafic rocks}

The mafic ultramafic suites in the Tulu Kapi gold mineralization is the group of rock exposures bounding for the goldfield of the area. It is comprised of chlorite-actinolite-talc schist, serpentines, pyroxenite, dunite, and Birbirite (named after the nearby Birbir River) within the ultramafic unit (Warkisa et al., 2020).

\section{Deformation and Metamorphism}

In Tulu Kapi area, structural shear-zone formations together with geological Intrusion represents one type of critical control on ore mineralization and served as enhancing fluid flow and alteration of host rocks. The resource area is principally underwent complex structural 
features with intensive polyphase ductile, brittle- ductile overprinting deformation resulting in numerous regionally penetrative NE-SW planar and linear features (Johnson et al. 2004, Molnar, 2019). Several studies in the WES identified five deformational events which are intended to observe based on the concept of overprinting relationships (e.g. Kebede et al., 1999; Johnson et al. 2004, Molnar, 2019). The first, D1, is defined by the Tulu dimtu and Bedele shear zones, along which the Tulu Kapi syenite is found. These shear zones are thought to have been dilatational conduits that focused intrusion of the syenite magma. D2 is the earliest deformation event that effected the syenite. While its kinematics is not certain, D2 resulted in vertical faults which are overprinted by D3 deformation. D3 reflects a compressional regime with reverse faulting, which then evolved to strike-slip for D4. D5 is interpreted as late extensional tectonics during orogenic collapse. Although Metamorphism of the region is note well investigated as of (Ayalew et al., 1990), two regional metamorphic events (M1 and M2) affected the WES as suggested by (Johnson et al. 2004). The Arabian Nubian Shield at Tulu Kapi consisted of Meta Volcano sedimentary dominated sequences with variety of sandstones and graphitic schists intruded by granites, syenites and diorites (Warkisa et al., 2020). The Mineral assemblages in these sequential terrains imply a maximum of greenschist to epidoteamphibolite facies within the Arabian Nubian Shield. The mineralogical constraints of this rocks (Molnar. 2019) interpreted to have undergone greenschist facies regional metamorphism based on their mineralogy and field appearance.

\section{Alteration and Gold Mineralization}

The Tulu Kapi province has a distinctive Precambrian basement rock which is highly characterized by prominent hills of intrusive rocks and deeply incised valleys containing metasediments and meta-volcanic rocks. The gold mineralization at Tulu Kapi area has been hosted by Syenite associated with alteration zones of albitization stacked lenses which host various 
phases of quartz veins and overprinting Sulphide veins and disseminations of structurally controlled alterations (Pollard, 2008). The main mineralization stage at Tulu Kapi is composed of an assemblage of hydrothermal minerals including quartz, albite, carbonate, biotite, muscovite, epidote, sulphides and gold (Molnar, 2019; Warkisa et al., 2020). The mineralization commonly occurs in veins, crackle zones and minor breccia zones. The syenite albitization is the one hosting for the gold mineralization and it has been widely overprinted by a multistage hydrothermal system that appears to have been controlled mainly by fractures and minor breccia zones (Pollard. 2007). Typically, the Tulu Kapi gold mineralization is mostly associated with sulphides bearing albite alteration, quartz veins and structurally controlled following the fracture fillings and orientation of the foliations Molnar, 2019, Pollard. 2007).

\section{Geochemistry}

The whole rock geochemical results from analysed dominant rock units from gold hosting Tulu kapi syenite area have $\mathrm{SiO}_{2}$ contents $54.9-77.2$ wt. \%, high $\mathrm{Al}_{2} \mathrm{O}_{3}(14-17$ wt. \%), high range of $\mathrm{Fe}_{2} \mathrm{O}_{3}\left(\sim 2-12\right.$ wt. \%), low $\mathrm{CaO}\left(0.11-2.78\right.$ wt. \%), high range of $\mathrm{Na}_{2} \mathrm{O}(\sim 3-9$ wt. $\%)$, high range of $\mathrm{K}_{2} \mathrm{O}\left(0.4-6\right.$ wt. \%), and very low (< 1 wt. \% each) $\mathrm{MgO}, \mathrm{TiO}_{2}, \mathrm{MnO}$ and $\mathrm{P}_{2} \mathrm{O}_{5}$ (Kebede et al., 1999; Warkisa et al., 2020) (Fig. 3). On the other hand, the diorites have $\mathrm{SiO}_{2}$ content of $\sim 44-45$ wt. \%, intermediate $\mathrm{Al}_{2} \mathrm{O}_{3}\left(13-14\right.$ wt. \%), high $\mathrm{Fe}_{2} \mathrm{O}_{3}(\sim 2-12$ wt. \%), $\mathrm{CaO}\left(7-9\right.$ wt. \%), $\mathrm{MgO}(4-5$ wt. $\%), \mathrm{TiO}_{2}\left(>1\right.$ wt. \%), proportional $\mathrm{K}_{2} \mathrm{O}$ and $\mathrm{Na}_{2} \mathrm{O}$ contents ( 2 - 3 wt. \% each), and very low $\left(<1\right.$ wt. \% each) $\mathrm{MnO}$ and $\mathrm{P}_{2} \mathrm{O}_{5}$ contents. The meta-granite shows similar composition to the syenites except its markedly higher $\mathrm{CaO}$ content ( 4 wt. \%). The mafic dike and the chlorite schist (serpentinite) have markedly low $\mathrm{SiO}_{2}$ and very high mafic oxide ( $\mathrm{MgO}, \mathrm{Fe}_{2} \mathrm{O}_{3}$, and $\mathrm{TiO}_{2}$ ) content (Kebede et al., 1999; Warkisa et al., 2020).

The effects of hydrothermal alteration and mineralization is observed from the geochemical signature of intrusive rocks around Tulu kapi area i.e., the significantly lower than $100 \%$ total 
of the oxides (which is as low as $\sim 95$ wt. $\%$ in the albitized syenites and $\sim 86$ wt. $\%$ in the diorites) indicates the strong alteration and loss of mobile elements (such as $\mathrm{K}, \mathrm{Mg}$ and $\mathrm{Ca}$ ) and remobilization of others (such as Na) (Warkisa et al., 2020).

The Tulu Kapi intrusive rocks are calc-alkaline (Kebede et al., 1999; Johnson et al. 2004; Warkisa et al., 2020), although some of the samples fall in the tholeiitic (sub-alkaline) field in the AFM diagram (Fig. 4), due possibly to the mobilization of mafic minerals such as $\mathrm{MgO}$ during alteration, pushing the samples closer to higher $\mathrm{Fe}_{2} \mathrm{O}_{3}$ (Warkisa et al., 2020). This is supported by the ferroan nature of all the intrusives (Fig. 5).

Based on alumina saturation index (ASI), Kebede et al., 1999; Warkisa et al., 2020 classified Tulu kapi syenite into marginally metaluminous and peralkaline varieties suggesting the syenites are alumina saturated and/or oversaturated (Fig. 5).

Further, Kebede et al., 1999 elucidated that the Tulu kapi syenite is enriched by the high field strength elements and depleted with large ion lithophile elements normalized to ORG. Later, Warkisa et al., 2020 reported that Tulu kapi syenite are slightly enriched in incompatible LILE (large-ion Lithophile elements) (Fig. 6) and depleted in HFSE (High field strength elements) (Fig. 7). The chondrite normalized REE plot of Tulu kapi syenite suggest that, the Tulu kapi syenite is slightly enriched by LREE and slightly depleted in HREE with variable negative EU anomaly (Kebede et al., 1999 and Geleta et al., 2020). The relatively higher values of Eu in some samples of Tulu kapi syenite is due to the presence of high contents of $\mathrm{Sr}$ and $\mathrm{Ca}$, for which $\mathrm{Eu}^{2+}$ substitutes in the plagioclase mineral.

\subsection{Tectonic Setting}

The Tulu kapi syenite has been interpreted as Within Plate Granite (WPG) and is related to subduction volcanism or continent-continent collision process (Kebede et al., 1999). Radian et al., 1981 suggested that the emplacement of peralkaline granites took place in a final phase of 
Pan African magmatic activity that built ANS. Similar A-type granitoids of Pan African age were also reported from granitoids of ANS in Sudan (Harris et al., 1983). However, Warkisa et al., 2020 interpreted as VAG and VAG+Syn-COLG to Within Plate Granite (WPG) using whole rock geochemical analysis (Fig. 8). Warkisa et al., 2020 further suggested that the albitized syenites are the Oceanic Ridge granites (ORG), indicating the possible remobilization of these trace elements (particularly the more compatible Rb). Warkisa et al., 2020 further proposed that the Tulu kapi syenite are probably are mantle-derived and modified by subduction-related magmatism that involves underplating and partial melting of basaltic materials, which are characterized by selective enrichments in LILE (Harris et al., 1986).

However, metamorphic alteration in the Tulu Kapi intrusives might have induced element mobility, particularly of the Large Ion Lithophile (LIL) elements (Rollinson, 1993; Tadesse and Allen, 2005), over-printing the original geochemical signature. For instance, the Rb enrichment in the quartz syenite is likely associated to K-silicate and sericitic alteration (due to the growth of secondary biotite and muscovite, respectively), while the Rb depletion in the albitized syenite samples could be related to chloritization and argillic alteration, due to breakdown of feldspar and mica (Pearce et al., 1984). Nevertheless, the general enrichment of the LILE relative to the HFS elements in the intrusive rocks is a subduction zone signature suggesting their derivation from calc-alkaline magmas with possibly significant melting of silicic crustal fragments, or even partial melting of crustal material.

\subsection{Age and Emplacement of gold hosting Tulu kapi Syenite}

The Neoproterozoic (900-600 Ma) Arabian Nubian Shield is an example of Precambrian plate tectonics and arc accretion (Kroner et al., 1992). The extension of ANS into western Ethiopia has been evidenced by the presence of low-grade metavolcanic and metasedimentary rocks in association with mafic and ultramafic rocks (Kazmin et al., 1978; Davidson, 1983) and subsequent geochemical and isotopic studies of the rocks of Birbir area suggests that this WES 
is an integral part of the ANS (Teklay et a., 1986; Ayalew and Moore, 1989; Ayalew et al., 1990). The Birbir domain of WES within which Tulu kapi syenite found in is underlain predominantly by plutonic rocks ranging in composition from gabbros to granite including syenite with U-Pb zircon ages of 830-540 Ma (Ayalew et al., 1990). The oldest age in Birbir domain is obtained on the Birbir quartez-diorite (830 Ma) and Goma granitoid (814 Ma) (Wolde et al., 1996). Oceanic magmatism in the ANS started not much earlier than $850 \mathrm{Ma}$ (Kroner et al., 1992). Based on this it's concluded that the $>800$ Ma Birbir plutons were emplaced during a time of widespread subduction the region (Wolde et al., 1996). Later the Birbir rocks were metamorphosed to lower amphibole facies, and deformed and mylonitised between 760-635 Ma (Ayalew et al., 1990). The ${ }^{206} \mathrm{~Pb} /{ }^{238} \mathrm{U}$ dates for the Tulu Kapi syenite and the Kapi gabbro, both of which host gold mineralization, are $738.3 \pm 2.6 \mathrm{Ma}$ and $699.5 \pm 2.7$ Ma, respectively (Molnar, 2019). The post-tectonic Genji granite, with a ${ }^{206} \mathrm{~Pb} /{ }^{238} \mathrm{U}$ age of $584 \pm 10 \mathrm{Ma}$ (Blades et al., 2015), sits along the Tuludimtu shear zone to the south of the Tulu Kapi syenite. Thus, Gold mineralization is constrained between the crystallization ages of the Kapi gabbro and Genji granite, $699.5 \pm 2.7$ Ma to $584 \pm 10$ Ma respectively.

Gold mineralization in greenstone belts is typically syn-metamorphic. The presence of hexagonal euhedral habits of pyrite, but not in alteration zones containing polymetallic sulfides, suggest that the sulfides in the alteration zone are pre or syn-peak-metamorphic (Craig and Vokes, 1993). Hence, the alteration zones are most likely to be either earlier than or coeval with gold mineralization. Metamorphism is documented between 635 and 580 Ma in the WES (Ayalew et al., 1990). This age for metamorphism sits within the age constraints provided by the Tulu Kapi and Genji intrusions that broadly bracket the timing of gold mineralization. The age of the Tulu Kapi syenite $(738.3 \pm 2.6 \mathrm{Ma})$ represents a time in the Tuludimtu belt when arc formation is thought to have occurred in the ANS (Johnson et al., 2011). Thus, Fluid generated 
during metamorphism during or after orogenesis in the WES may have scavenged and transported gold prior to transport through the crust via structurally-controlled faults and shear zones.

\subsection{Origin of Gold and gold bearing Tulu kapi Syenite}

Suits of rocks generated by partial melting shows large variation in incompatible element abundances and little or no variation in the contents of compatible elements (Kebede et al., 1999 and reference there in). However, rocks which are generated by fractional crystallization shows relatively considerable variation in compatible elements whereas the incompatible elements remain less sensitive for low to moderate degree of fractionation.

The decreasing $\mathrm{CaO}, \mathrm{Fe}_{2} \mathrm{O}_{3}, \mathrm{MgO}$ contents with increasing silica in syenite suggests fractional crystallization of plagioclase and mafic minerals during basaltic magma differentiation followed by hydrothermal alteration (Kebede et al., 1999; Warkisa et al., 2020). $\mathrm{K}_{2} \mathrm{O}$ and $\mathrm{Na}_{2} \mathrm{O}$ show a contrasting decreasing and increasing trend along the same silica differentiation line, suggesting the albitization of the feldspars during hydrothermal alteration in these rocks (Kebede et al., 1999; Warkisa et al., 2020). Mantle generated basaltic magma in a subduction setting would initially crystallize Ca-rich plagioclase and upon cooling continually react with hydrothermal fluids to more fractionated Na-rich plagioclase.

Most subduction setting granitic intrusions in the ANS of Ethiopia have been largely associated to calc-alkaline suites (Asrat et al., 2001), which is also supported by the dominance of calcalkaline granites in Syn-collisional/subduction-related settings of other parts of the ANS (Bentor, 1985). The Alumina Saturation Index (ASI) indicated that the intrusive rocks at Tulu kapi are metaluminous to peraluminous (Kebede et al., 1999; Warkisa et al., 2020) while the syenites, particularly the albitized ones as slightly peraluminous (Warkisa et al., 2020). 
Thus, the clear division of the syenites as peraluminous (S-type granites) from the other metaluminous intrusions (I-type granites) possibly indicates different magma sources to these categories of intrusions. Several works show (e.g., Frost et al., 2001 and references therein) peraluminous (S-type granites) are generated by partial melting of metasedimentary rocks as a result of thermal relaxation of the orogenic belts at syn-collisional suites. The gold mineralization hosting syenites of Tulu Kapi which are high silica, mica-bearing, dominated by sodic feldspar and aluminum-rich minerals, with little or no mafic minerals could therefore be associated to partially molten magma at syn-collisional/subduction zones (Kebede et al., 1999; Warkisa et al., 2020).

There are two commonly evoked sources of fluids in greenstone-hosted orogenic gold deposits, metamorphic and magmatic (Phillips and Powell, 2010; Goldfarb and Groves, 2015). The association of minor galena with gold is suggestive of an igneous-derived fluid (Goldfarb and Groves, 2015).

However, the paucity of sulfides (other than pyrite and pyrrhotite) is more consistent with a metamorphic-derived fluid (Groves et al., 2003). The only known syn-kinematic magmatism along the Tuludimtu shear zone which postdates the Kapi gabbro is the Dogi Granite $50 \mathrm{~km}$ to the north of Tulu Kapi with a U-Pb titanite age of $651 \pm 5 \mathrm{Ma}$ (Grenne et al., 2003). The source of fluids for the gold mineralization of Tulu Kapi could be from intrusive events that emplaced the Kapi gabbro or the Dogi granite. The timing of metamorphism is 635 to $580 \mathrm{Ma}$ (Ayalew et al., 1990). Therefore, magmatism or metamorphism could have been the source for fluids for the gold mineralization of Tulu Kapi. 


\section{Conclusion}

Extensive research on the formation of gold deposits, to produce a range of genetic exploration models applicable to the Ethiopian geologic context is necessary.

- The major and trace element composition of ore-forming fluids related to intrusionrelated gold mineralization is still largely unknown in the Western Ethiopian gold bearing green stone belts, yet could provide important and more direct evidence for the fluid source(s).

- There is a contradiction on the age of Tulu Kapi Syenite i.e., Kebede et. al., (1999) suggested that the Tulu Kapi syenite was post-tectonic while Molnar (2019) concluded that it is pretectonic. Thus, required detail analysis to determine whether Tulu Kapi Syenite is posttectonic or pre-tectonic.

- The type, source, and physicochemical conditions of the gold mineralizing fluid is yet to be elucidated.

- Stable isotope $(\mathrm{O}, \mathrm{S}, \mathrm{H})$ analysis of the quartz, pyrite grains from gold bearing quartz veins and Syenite rocks provide a means of elucidating type, source, and physicochemical conditions mineralizing fluid.

- Establishing a genetic link between gold and Syenite intrusions is pivotal in this case.

- Detail fluid inclusion studies on Syenite-related gold mineralization in Western Ethiopia could provide an answer to the obscured genetic relationship of gold with crustal processes known to modify gold-rich alkalic magmas.

- Studying fluid inclusions in quartz grains from the gold-bearing veins, barren veins and the non-mineralized part of the Syenite intrusion to determine the temporal relationship between inclusions hosting gangue phases and Au ore mineral, by assessing the 
composition of the mineralizing and non-mineralizing fluid/melt, is an unexploited avenue which could be used to establish this genetic link.

- Advances in analytical techniques using fluid inclusions trapped in quartz grains from gold bearing veins/rocks provide a means of elucidating the factors controlling gold concentration and ultimate source, by studying the properties of these fluids which hold evidence of ore formation.

- Thus, detail alteration fluid chemistry and determination of whether gold-bearing fluids were metamorphic or magmatic in origin could assist with gold exploration in the proximity of the Tulu Kapi Gold Deposit of Western Ethiopia.

\section{Acknowledgement}

We appreciate the previous authors for their contributions used in this work.

\section{References}

Abraham, S., Bheemalingeswara, K., Gebreselassie, S., 2015. Geology of volcanogenic massive sulfide deposit near Meli, northwestern Tigray, northern Ethiopia. Momona Ethiopian Journal of Science (MEJS), V7(1):85-104, 2015.

Asrat, A., Barbey, P., Gleizes, G., 2001. The Precambrian Geology of Ethiopia: a review. Africa Geosciences Review, 8: 271-288.

Ayalew T., Bell K., Moore J. M., and Parrish R. R., 1990. U-Pb and Rb-Sr geochronology of the Western Ethiopian Shield. Geological Society of America Bulletin, volume 102, 13091316.

Ayalew T., Peccerillo A., 1998. Petrology and geochemistry of the Gore-Gambella plutonic rocks: implications for magma genesis and the tectonic setting of the Pan-African Orogenic Belt of western Ethiopia. Journal of African Earth Sciences 27, 397-416.

Ayalew, T., Moore, J. M., 1989. Final Report of the Gore-Gambella Geotraverse, western Ethiopia. International Development Research Centre (IDRC), Canada, 153pp.

Bentor, Y.K., 1985. The crustal evolution of the Arabo-Nubian Massif with special reference to the Sinai Peninsula. Precambrian Research, 28(1): 1-74. 
Blades M. L., Collins A. S., Foden J., Payne J. L., Xu X., Alemu T., Woldetinsae G., Clark C., Taylor R.J.M., 2015. Age and hafnium isotopic evolution of the Didesa and Kemashi Domains, western Ethiopia. Precambrian Research 270, 267-284.

Craig J. R. and Vokes F. M., 1993. The metamorphism of pyrite and pyritic ores: and overview. Mineralogical Magazine, Volume 57, 3-18.

Davidson, A., 1983. The Omo River project: reconnaissance geology and geochemistry of parts of Illubabor, Kefa, Gemu Gofa and Sidamo. Ethiopia. Eth. Inst. Geol. Surv. Bull. 2. 88p.

Deksissa, Debele J., \& Koeberl, C. (2004). Geochemistry, alteration, and genesis of gold mineralization in the Okote area, southern Ethiopia. Geochemical Journal, 38(4), 307331. https://doi.org/10.2343/geochemj.38.307

Frost, B.R., Barnes, C.G., Collins, W.J., Arculus, R.J., Ellis, D.J., Frost, C.D., 2001. A geochemical classification for granitic rocks. Journal of Petrology, 42(11): 2033-2048.

Goldfarb R. J., Baker T., Dube B., Groves D. I., Hart C. J. R., Gosselin P., 2005. Distribution, Character, and Genesis of Gold Deposits in Metamorphic Terranes. Economic Geology $100^{\text {th }}$ Anniversary Volume, 407-450.

Goldfrab R. J. and Groves D. I., 2015. Orogenic gold: Common or evolving fluid and metal sources through time. Lithos, volume 233, 2-26.

Grenne T., Pedersen R. B., Bjerkgard T., Braathen A., Selassie M. G., Worku T., 2003. Neoproterozoic evolution of the Western Ethiopia: igneous geochemistry, isotope systematics and U-Pb ages. Geological Magazine 140: 373-395.

Groves D. I., Goldfrarb R. J., Robert F., and Hart C. J. R., 2003. Gold Depoists in Metamorphic Belts: Overview of Current Understanding, Outstanding Problems, Future Research, and Exploration Significance. Journal of Economic Geology, Volume 98, 1-29.

Harris, N.B.W., Duyverman, H.J., Almond, D.C., 1983. The trace element and isotope geochemistry of the Sabaloka Igneous complex, Sudan. Journal of Geological Society of London. 140, 245-256.

Hart, C.J.R., Goldfarb, R.J., Lewis, L.L., and Mair, J.L. (2004). The Northern Cordillera MidCretaceous Plutonic Province: Ilmenite/magnetite-series granitoids and intrusion- related mineralisation: Resource Geology, 54 (3), 253-280. 
Irvine, T.N., Baragar, W.R.A., 1971. A guide to the chemical classification of the common volcanic rocks. Canadian Journal of Earth Sciences, 8: 523-548.

Johnson P. R., Zoheir B. A., Ghebreab W., Stern R. J., Barrie C. T., Hamer R. D., 2017. Goldbearing volcanogenic massive sulfides and orogenic-gold deposits in the Nubian Shield. South African Journal of Geology, Vol 120.1, 63-76.

Johnson T. E., Ayalew T., Mogessie A., Kruger F. J., Poujol M., 2004. Constraints on the tectonometamorphic evolution of the Western Ethiopian Shield. Precambrian Research $133,305-327$.

Johnson, P. R., Andresen, A., Collins, A. S., Fowler, A. R., Fritz, H., Ghebreab, W., ... Stern, R. J. (2011). Late Cryogenian-Ediacaran history of the Arabian-Nubian Shield: A review of depositional, plutonic, structural, and tectonic events in the closing stages of the northern East African Orogen. Journal of African Earth Sciences, 61(3), 167-232. https://doi.org/10.1016/j.jafrearsci.2011.07.003

Kazmin, V., Shiferaw, A., Tefera, M., Berhe, S.M., Chewaka, S., 1979. Precambrian structure of western Ethiopia. Annals Geological Survey Egypt 9, 1-8.

Kazmin, V., Shifferaw, A., \& Balcha, T. (1978). The Ethiopian basement: Stratigraphy and possible manner of evolution. Geologische Rundschau, 67(2), 531-546.

Kebede H. Belete, Aberra Mogessie and John F.W. Bowles (2002). Platinum-Group Minerals in the Alaskan Type Mafic-Ultramafic Intrusions of the Yubdo Area, Western Ethiopia. Retrieved from $\quad$ https://nicholas.duke.edu/people/faculty/boudreau/9thPtSymposium/Belete_Abstract on 26.05.2016

Kebede, T., Koeberl, C., Koller, F., 1999, Geology, Geochemistry and petrogenesis of intrusive rocks of the Wallagga area, Western Ethiopia, Journal of African Earth Sciences, Vol. 29, No. 4, pp 715 - 734.

Kroner, A., Pallister, J.S., and Fleck, R.J., 1992. Age of initial oceanic magmatism in the Late Proterozoic Arabian Shield. Geology, 20: 803-806.

McBirney, A.R., 1984. Igneous Petrology. San Francisco, CA: Freeman, Cooper.

Mengesha Tefera and Seife Michael Berhe (1987). Geology of sheet NC, 36-16, (Gore sheet). Ethiopian Institute of Geological Surveys. Unpublished report.

Pearce, J. A., Harris, N.B.W., Tindle, A.G., 1984. Trace element discrimination diagrams for the tectonic interpretation of granitic rocks. Journal petrology 25, 956-983. 
Phillips, G. N., \& Powell, R. (2009). Formation of gold deposits: Review and evaluation of the continuum model. Earth-Science Reviews, 94(1-4), 1-21. https://doi.org/10.1016/j.earscirev.2009.02.002

Pollard, P.J., 2008. Gold mineralisation and associated alteration at the Tulu Kapi prospect, Ethiopia: Recommendations for future work. Private report - Minerva Resources Pty Ltd, 18p.

Radian, A.A.M., Fyfe, W.S., Kerrich, R., 1981. Origin of peralkaline granites of Saudi Arabia. Contributions Mineralogy Petrology 78, 358-366.

Rollinson, H.R. (1993). Using Geochemical Data: Evaluation, Presentation, Interpretation. Addison Wesley Longman, Harlow, England, 352p.

Stern R. J., 1994. Arc Assembly and Continental Collision in the Neoproterozoic East African Orogen: Implications for the Consolidation of Gondwanaland. Annual Reviews of Earth and Planetary Sciences 22, 319-351.

Tadesse, G., \& Allen, A. (2004). Geochemistry of metavolcanics from the Neoproterozoic Tuludimtu orogenic belt, western Ethiopia. Journal of African Earth Sciences, 39 (3-5), 177-185. https://doi.org/10.1016/j.jafrearsci.2004.07.051

Tadesse, G., Allen, A., 2005. Geology and geochemistry of the Neoproterozoic Tuludimtu Ophiolite suite, western Ethiopia. J. Afr. Earth Sci., 41: 192-211.

Tadesse, S., Milesi, J. P., \& Deschamps, Y. (2003). Geology and mineral potential of Ethiopia: A note on geology and mineral map of Ethiopia. Journal of African Earth Sciences, 36(4), 273-313. https://doi.org/10.1016/S0899-5362(03)00048-4

Teklay, M., Moore, J. M., Morgan, J., Tefera, M., 1986. Precambrian geology of GoreGambella Geotraverse, Western Ethiopian Ethiopia. Newsletter 5, UNESCO, Geology for Economic Development, pp. 101-113.

Warkisa, G., Asrat, A., Omitogun, A., Oljira, T., 2020. Petrogenetic and geochemical characterization of gold mineralization hosting syenites in Tulu Kapi, western Ethiopia. Unpublished Thesis at Pan African University Life and Earth Science Institute, University of Ibadan, Nigeria.

Wolde, B., Gore-Gambella Geotraverse Team, 1996. Tonalite-trondhjemite-granite genesis by partial melting of newly underplated basaltic crust: an example from the Neoproterozoic Birbir Magmatic arc, western Ethiopia. Precambrian Research, 76: 3-14. 
Worku, H. and Schandelmeier, H. (1996). Tectonic Evolution of the Neoproterozoic Adola Belt of Southern Ethiopia: Evidence for a Wilson Cycle Process and Implications for Oblique Plate Collision. Precambrian Research, 77, 179-210. https://doi.org/10.1016/0301-9268(95)00054-2

Zsolt Molnar., 2019. The Tulu Kapi Gold Deposit of the Western Ethiopian Shield: Structural Framework, U-Pb Zircon Geochronology and Paragenesis. UW Space.

\section{Figure Captions}

Fig. 1. Geological map of the Western Ethiopian Shield in the vicinity of Tulu Kapi (after Johnson et al., 2004).

Fig. 2. Geological map of the Tulu Kapi area (modified after Kefi Minerals Ltd. Ethiopia, 2014).

Fig. 3. Major element variation diagrams of the Tulu Kapi intrusive rocks: $\mathrm{SiO}_{2}$ versus (a) $\mathrm{Fe}_{2} \mathrm{O}_{3}$; (b) $\mathrm{MgO}$; (c) $\mathrm{Al}_{2} \mathrm{O}_{3}$; (d) $\mathrm{CaO}$; (e) $\mathrm{Na}_{2} \mathrm{O}$; and (f) $\mathrm{K}_{2} \mathrm{O}$.

Fig. 4. The AFM classification diagram for the Tulu Kapi intrusive rocks; 1: boundary between calc-alkaline and tholeiitic fields from Irvine and Baragar (1971); 2: boundary between calc-alkaline and tholeiitic fields from McBirney (1984); A: total alkalis; F: total Iron; and M: MgO (after Warkisa et al., 2020).

Fig. 5. Classification of the Tulu Kapi intrusive rocks using (a) iron to magnesium ratio; and (b) alumina saturation index diagram (after Frost et al., 2001). 
Fig. 6. Primitive mantle-normalized trace element pattern of the Tulu Kapi intrusive rocks (normalizing values are from Sun and McDonough, 1989).

Fig. 7. Chondrite-normalized REE patterns of the Tulu Kapi intrusive rocks (normalizing values are from Nakamura, 1974).

Fig. 8. Tectonic discrimination of the Tulu Kapi intrusive rocks using (a) the $\mathrm{Rb}-(\mathrm{Y}+\mathrm{Nb}$ ) and (b) the Nb-Y diagrams. Tectonic boundaries are from Pearce et al. (1984). VAG: volcanic arc granites; ORG: oceanic ridge granites; WPG: within plate granites; Syn-COLG: syncollision granites. 


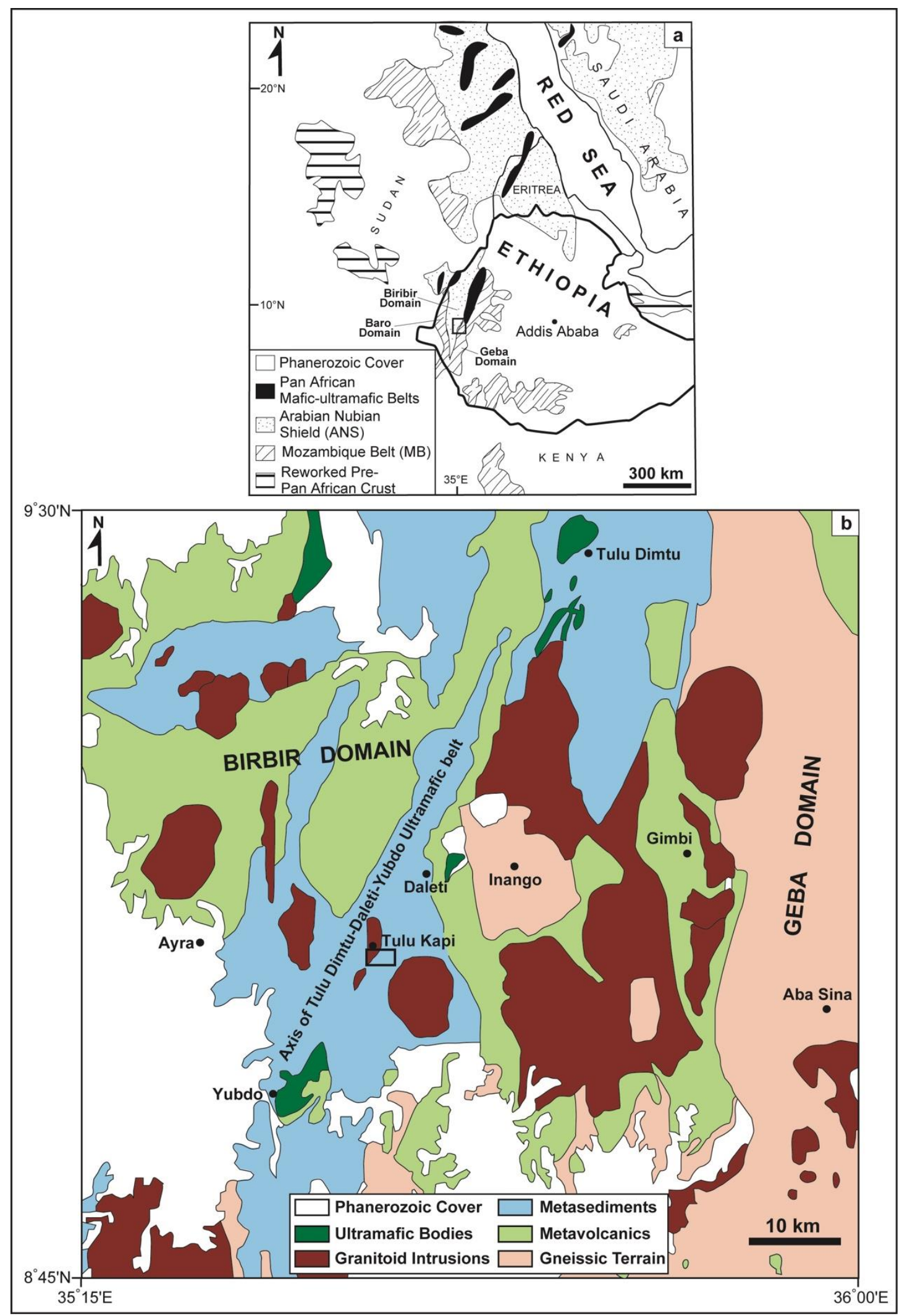

Fig. 1. Geological map of the Western Ethiopian Shield in the vicinity of Tulu Kapi (after Johnson et al., 2004). 


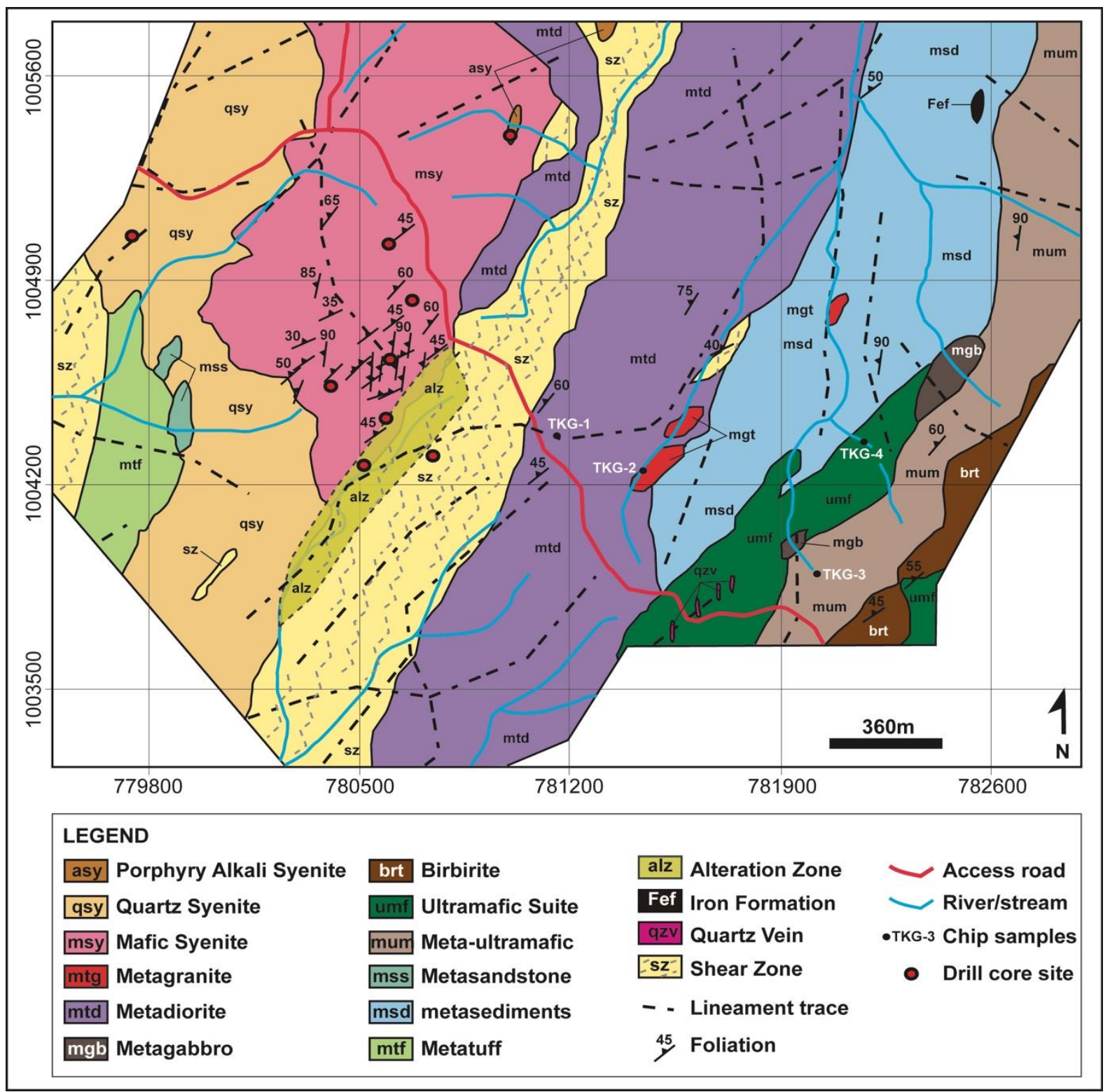

Fig. 2. Geological map of the Tulu Kapi area (modified after Kefi Minerals Ltd. Ethiopia, 2014). 

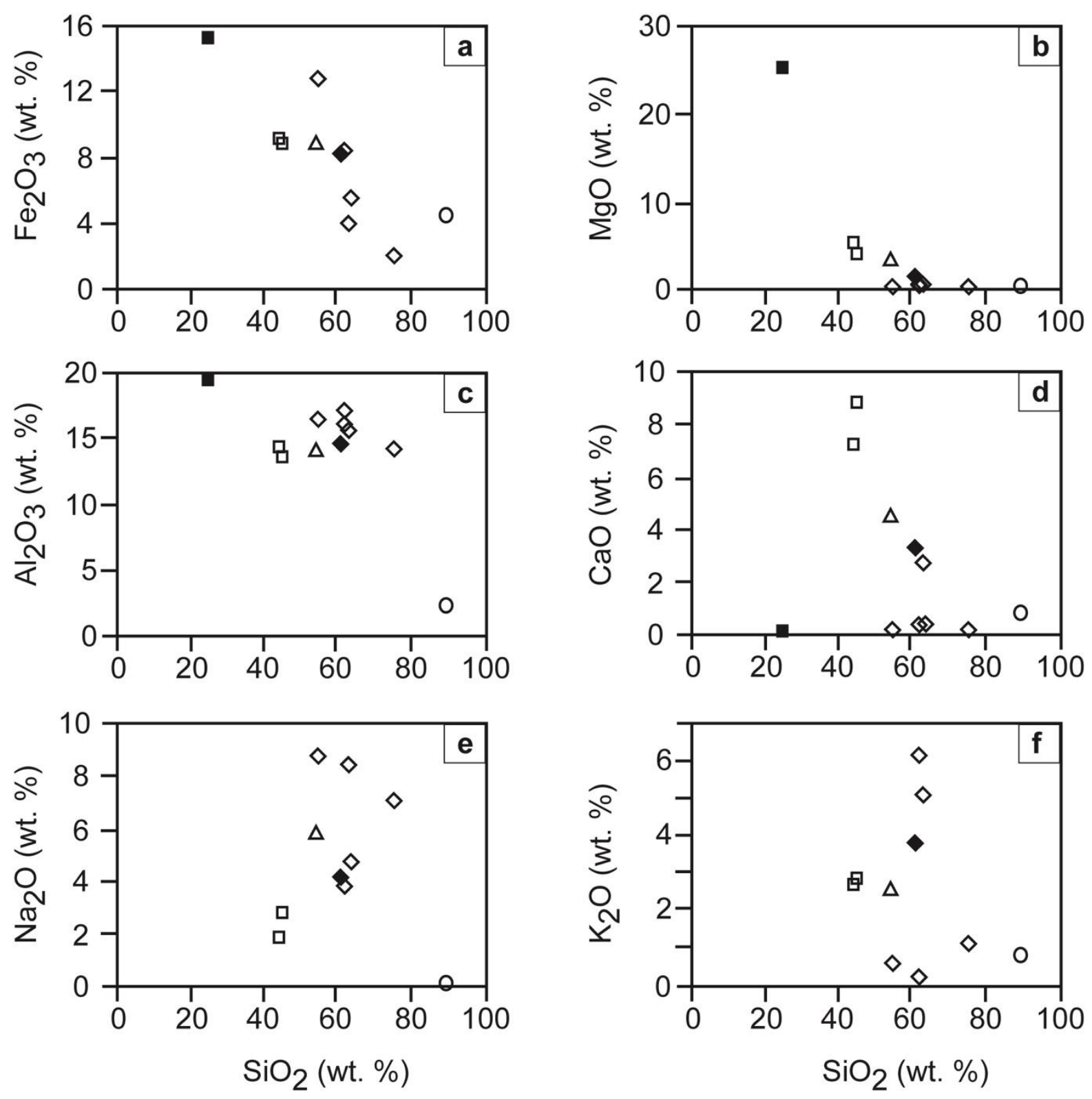

- Chlorite schist

$\Delta$ Mafic dike

$\diamond$ Syenite

口 Meta-diorite

- Meta-granite

○ Quartz vein

Fig. 3. Major element variation diagrams of the Tulu Kapi intrusive rocks: $\mathrm{SiO}_{2}$ versus (a) $\mathrm{Fe}_{2} \mathrm{O}_{3}$; (b) $\mathrm{MgO}$; (c) $\mathrm{Al}_{2} \mathrm{O}_{3}$; (d) $\mathrm{CaO}$; (e) $\mathrm{Na}_{2} \mathrm{O}$; and (f) $\mathrm{K}_{2} \mathrm{O}$. 


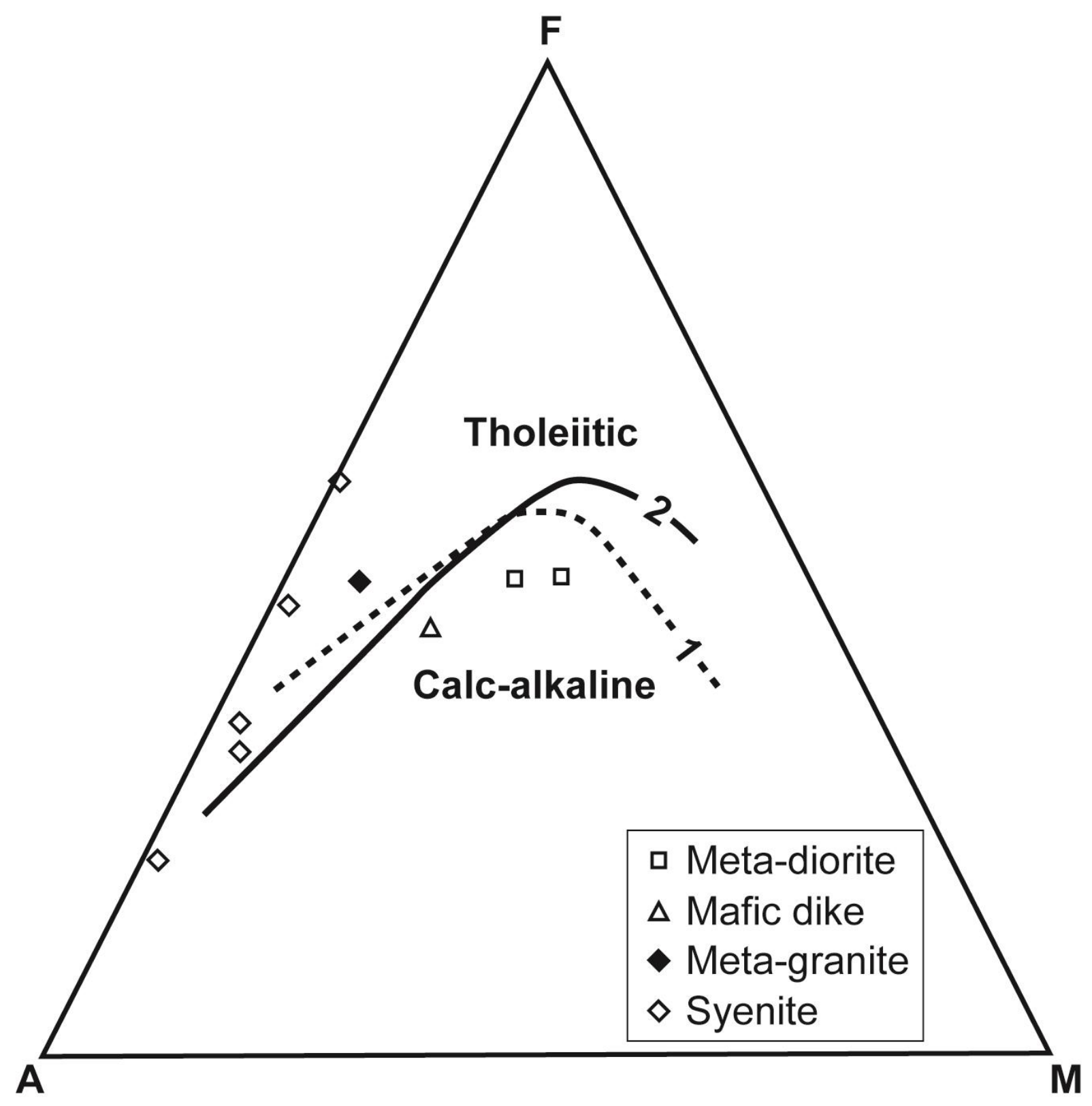

Fig. 4. The AFM classification diagram for the Tulu Kapi intrusive rocks; 1: boundary between calc-alkaline and tholeiitic fields from Irvine and Baragar (1971); 2: boundary between calcalkaline and tholeiitic fields from McBirney (1984); A: total alkalis; F: total Iron; and M: MgO. 

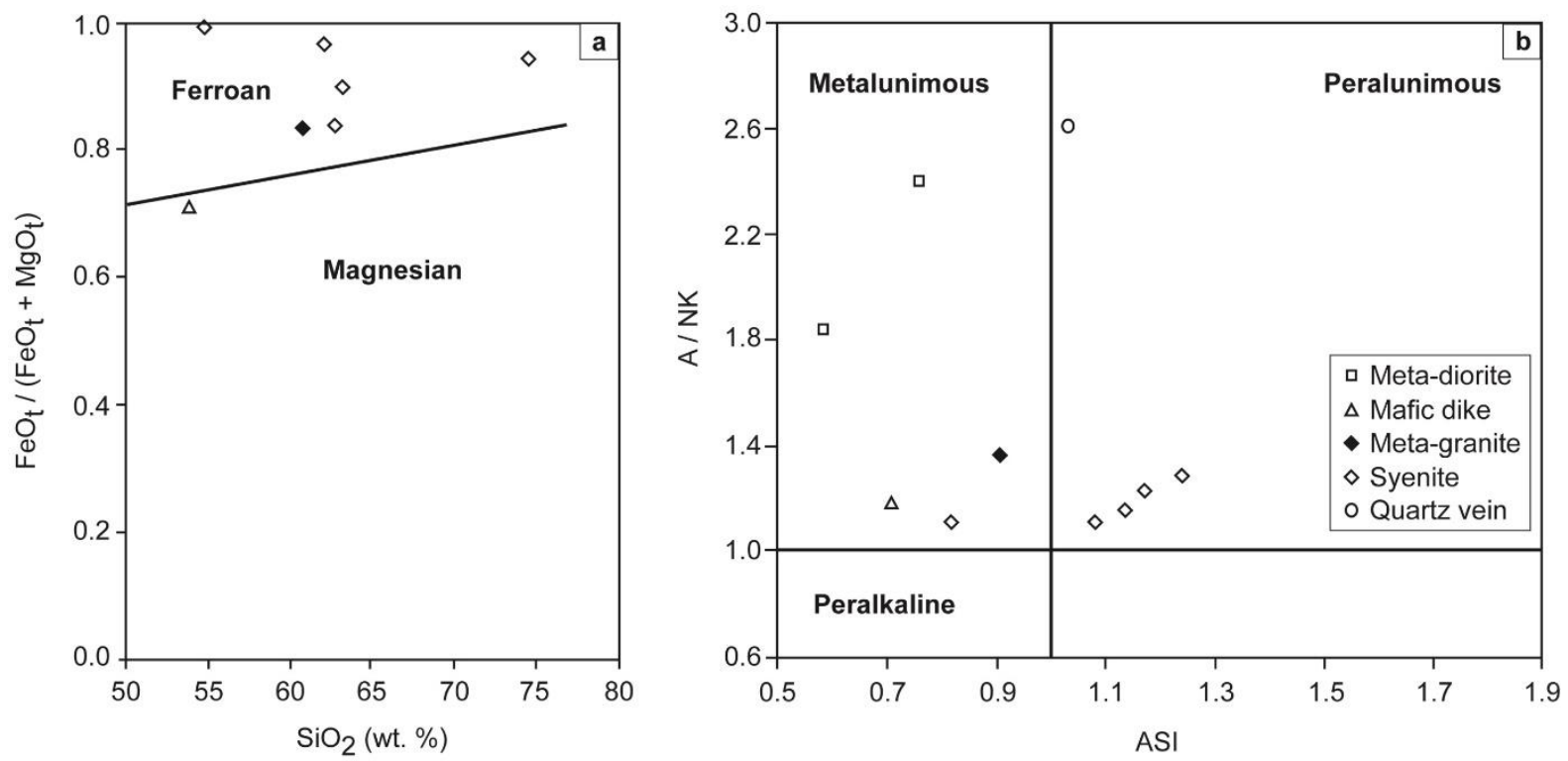

Fig. 5. Classification of the Tulu Kapi intrusive rocks using (a) iron to magnesium ratio; and (b) alumina saturation index diagram (after Frost et al., 2001).

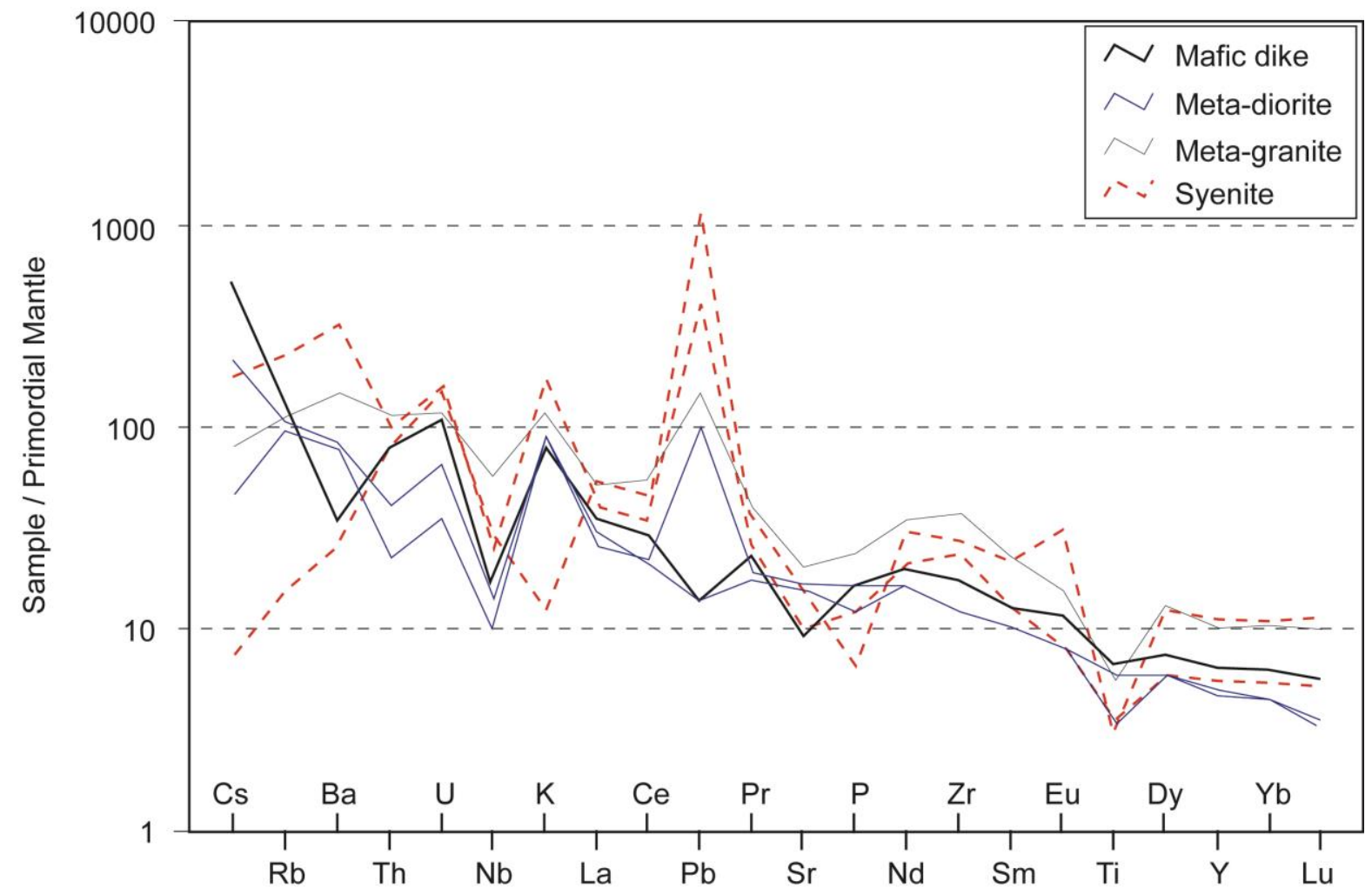

Fig. 6. Primitive mantle-normalized trace element pattern of the Tulu Kapi intrusive rocks (normalizing values are from Sun and McDonough, 1989). 


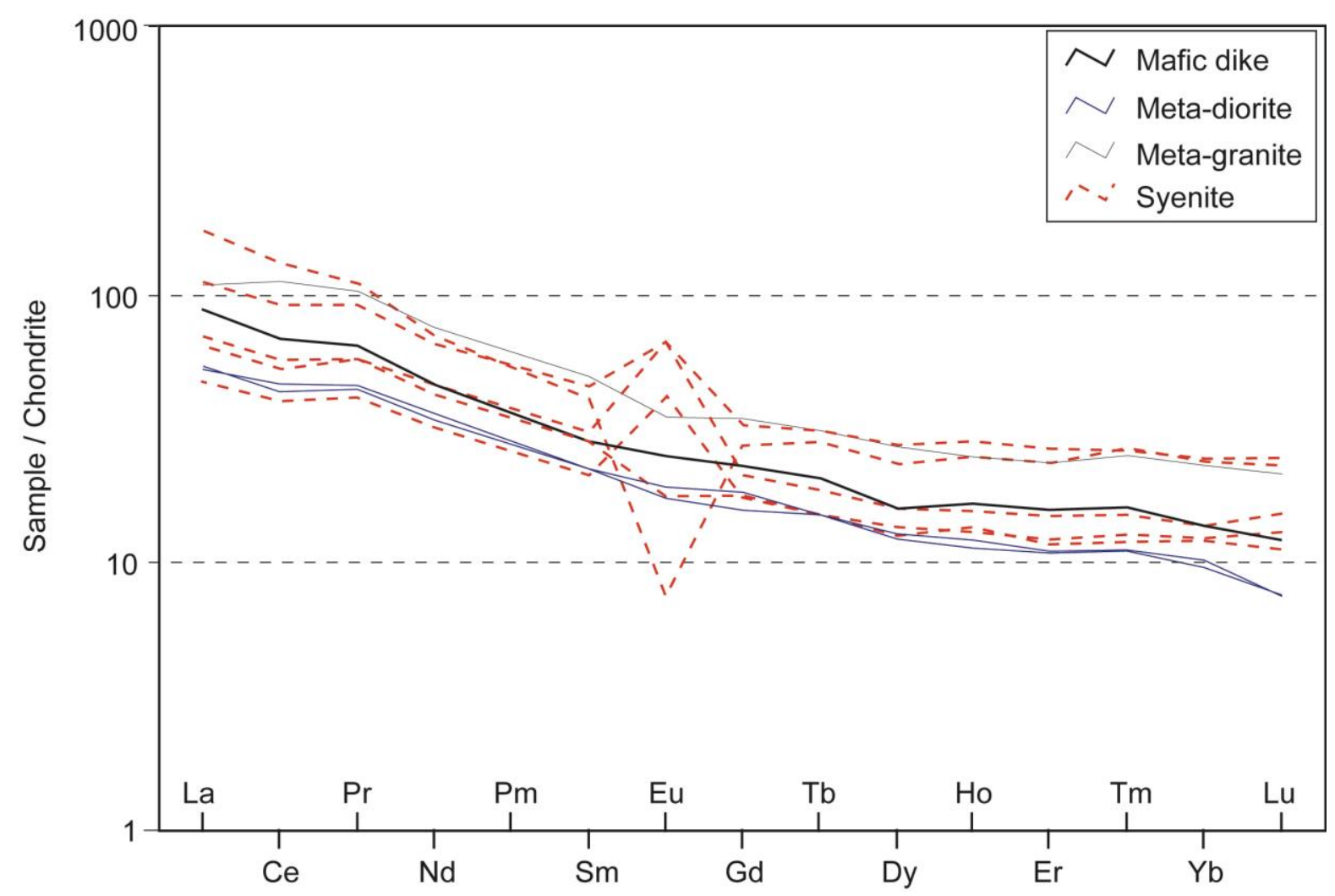

Fig. 7. Chondrite-normalized REE patterns of the Tulu Kapi intrusive rocks (normalizing values are from Nakamura, 1974).
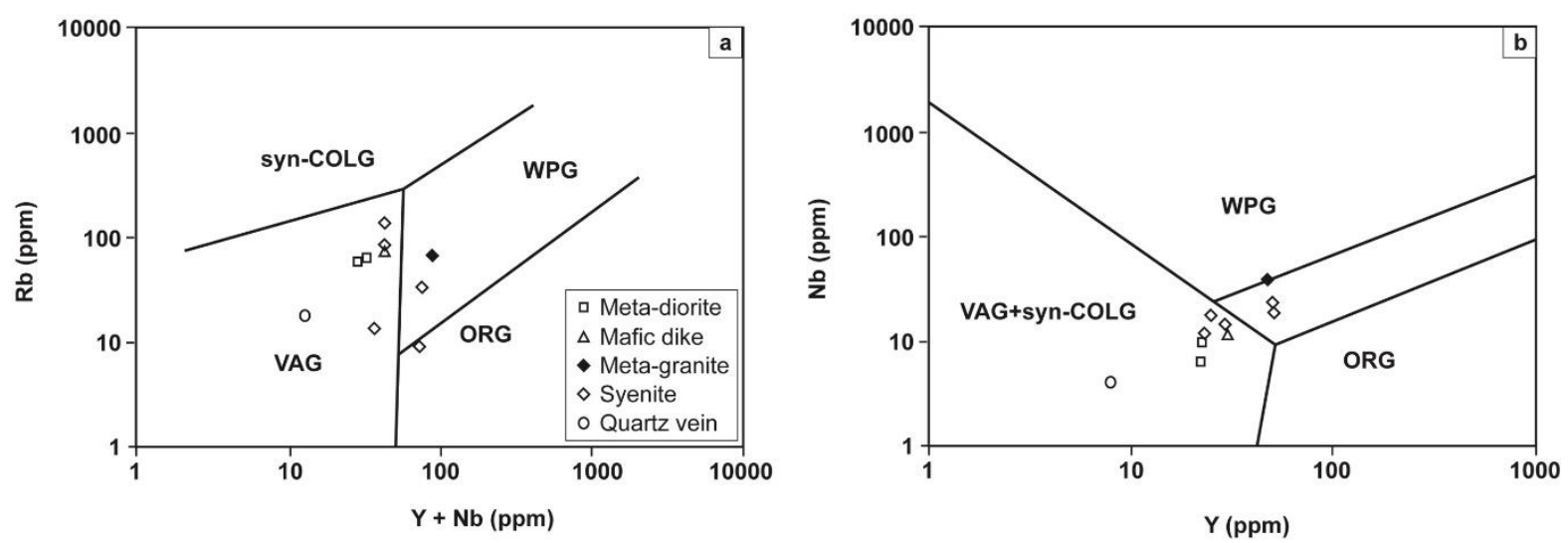

Fig. 8. Tectonic discrimination of the Tulu Kapi intrusive rocks using (a) the $\mathrm{Rb}-(\mathrm{Y}+\mathrm{Nb})$ and (b) the Nb-Y diagrams. Tectonic boundaries are from Pearce et al. (1984). VAG: volcanic arc granites; ORG: oceanic ridge granites; WPG: within plate granites; Syn-COLG: syn-collision granites. 